\title{
The Level and Sources of Foreign Language Speaking Anxiety among Saudi EFL University Students
}

Faye Alnahidh, Sultan Altalhab*

Curriculum and Instruction Department, College of Education, King Saud University, Riyadh, Saudi Arabia

Corresponding Author: Sultan Altalhab, E-mail: saltalhab@ksu.edu.sa

\section{ARTICLE INFO}

Article history

Received: October 04, 2019

Accepted: December 23, 2019

Published: February 29, 2020

Volume: 11 Issue: 1

Advance access: February 2020

Conflicts of interest: None

Funding: None

Key words:

Speaking,

Anxiety,

EFL,

FLA,

FLSA

\begin{abstract}
This study aims to investigate the level and the sources of Foreign Language Speaking Anxiety (FLSA). To achieve this aim, a mixed-method approach was used by implementing a questionnaire and interviews. Eighty-five female Saudi EFL university students completed the questionnaire. Six of the most highly anxious students were identified according to the questionnaire results and interviewed. The findings revealed that the participants experienced a moderate level of FLSA in their English class. In addition, there are several sources of FLSA, which can be listed in the following order: fear of making mistakes, forced participation, lack of vocabulary, lack of practice, lack of grammar. Participants also reported other sources of anxiety such as fear of making pronunciation mistakes, the negative attitude of teachers and the need to give oral presentations. Based on the results, the study reached a conclusion and constructed a set of recommendations.
\end{abstract}

\section{INTRODUCTION}

Many researchers such as Horwitz, Horwitz,\& Cope (1986) and Young (1992) have claimed that Foreign Language Anxiety (FLA) is one of the most psychologically debilitating phenomena that may negatively affect EFL learners' language learning. Young (1991) noted that EFL learners may have to deal with unnecessary levels of anxiety when learning EFL, leading to tension and stress which reduces their self-confidence. According to Horwitz (2001), FLA may inhibit the language learning process and is considered one of the most significant issues in psychology and education.

Researchers have defined FLA as a phenomenon related to apprehension. For example, Gardner and MacIntyre (1993) defined FLA as "the apprehension experience when a situation requires the use of foreign language and the individual is not fully proficient". In addition, Szyszka (2017) referred to FLA as the fear that a foreign language learner experiences while using a foreign language. Similarly, Horwitz et al. (1986) the first scholars to introduce the concept of foreign language anxiety, defined it as "a distinct complex of self-perceptions, feelings and behaviors related to classroom language learning arising from the uniqueness of the language learning process".

According to different studies, anxiety might be one of the most common phenomena experienced while learning
EFL. Many scholars assert that FLA is mostly observed in speaking classes (Gardner \& MacIntyre, 1993; Horwitz et al., 1986; MacIntyre, 1999; Young, 1992) because the students need to process linguistic input and produce their thoughts at the same time. Learners try to improve their speaking skills by taking part in a variety of classroom activities such as making oral presentations or participating in group discussions. These activities might be challenging and destructive to the learning process. Therefore, speaking in a foreign language is considered the most anxiety provoking element in the foreign language learning process. Moreover, Foreign Language Speaking Anxiety (FLSA) has motivated researchers to look into this common problem and try to reduce it (Heng, Abdullah \& Yosaf, 2012; Javid, 2014; Alsaraj, 2014; Alrabai, 2014; Rafada \& Madini, 2017).

Investigating the level and the sources of FLSA in the EFL classroom could provide valuable pedagogical insights for educators and policy-makers, helping them to develop effective teaching strategies to overcome FLSA. In addition, this study attempts to assist EFL teachers to develop teaching skills and help them create a less stressful learning environment. Moreover, this study may help EFL learners to become aware of their FLSA sources and as a result, they may overcome this problem and improve their English 
speaking skills. It is hoped that this study will contribute to the improvement of the EFL teaching and learning process and enrich research in this field.

\section{LITERATURE REVIEW}

\section{Anxiety as a Psychological Construct}

Although the current study focuses on foreign language speaking anxiety, it is vital to understand the general concept of anxiety in psychology. Anxiety is about destructive human feelings. Anxious people are often tense, worried, frustrated, nervous and apprehensive. Horwitz et al. (1986) defined anxiety as a phenomenon that comprises "the subjective feeling of tension, apprehension, nervousness, and worry associated with an arousal of the automatic nervous human system".

The proposed definitions of anxiety by several researchers have some common characteristics such as fear, apprehension, uneasiness (Horwitz \& Young, 1991). These characteristics are related to a person's negative evaluation of themselves and low self-esteem. Therefore, they avoid learning tasks such as speaking in front of their colleagues because they feel anxious in the learning process.

\section{Foreign Language Anxiety}

There are many definitions of FLA in the literature. In general, anxiety is most associated with foreign language learning. Gardner and MacIntyre (1993) defined FLA as the subjective feeling of tension and apprehension specifically associated with a foreign language context, which includes speaking, listening and learning.

Early FLA studies provide inconsistent evidence as well as confusing and mixed results; scholars were unable to establish a clear picture of the effect of FLA on learners (Horwitz \& Young, 1991). There were a number of opposing views on this issue and debates ensued. There have also been some studies showing the positive effect of FLA on the students' language learning.

In contrast, numerous studies found that FLA produced a negative effect on the students' language learning. Horwitz et al. (1986), the first scholars to introduce FLA as a separate phenomenon in education, conducted a study to investigate the level and sources of speaking anxiety using the Foreign Language Classroom Anxiety Scale (FLCAS). The participants were 78 American students studying Spanish as a foreign language. They found that FLA affected them negatively and the main sources of anxiety appeared to be listening and speaking. Similarly, Zhang (2010) investigated FLA among Chinese students by using FLCAS and the Young (1990) questionnaire. The results showed that speaking activities and the teachers' attitudes, in particular, would make the students anxious.

Furthermore, Aida (1994) conducted a study to examine the level of FLA among students studying Japanese as a foreign language at the University of Texas using FLCAS. The results showed that students faced FLA in the Japanese class. The students with higher anxiety were more likely to receive a low grade on the Japanese course. A study by Nahavandi and Mukundan (2013) investigated Iranian EFL learners to identify the level and the sources of FLA using FLCAS. The results revealed that the participants exhibited a high level of FLA. However, among all the four language skills (reading, writing, listening and speaking) speaking is considered the most anxiety-provoking element in language learning.

To sum up, although there were some studies noticing the facilitating effect of FLA on the language learning process, the majority of language researchers have reported that FLA is a debilitating element in the language learning context (Toth, 2010). Thus, Horwitz (1990) claims that FLA is debilitating for language learning and that there is no existence of its facilitating effect in language learning. Along the same line, MacIntyre and Gardner (1991) have argued that language anxiety has a consistently negative effect on language learning ability and production. It is worthwhile to mention that the current study also considers FLA as debilitating and will investigate the debilitative nature of FLSA.

\section{Components of Foreign Language Anxiety}

Horwitz et al. (1986) identified three main components to foreign language anxiety: communication apprehension, test anxiety, and the fear of negative evaluation. It is essential to mention that FLA might not only be a combination of these three. Moreover, the three components might be a foundation for understanding the possible sources of FLA and FLSA in particular, since speaking is the main focus of the current study.

\section{Communication apprehension}

Communication apprehension is the fear that an individual experiences in oral communication (Horwitz et al., 1986; Daly, 1991). It is related to speaking activities and the embarrassment that learners face when they perform in the foreign language classroom, which is the main focus of the current study. Communication apprehension may be associated with first or second language acquisition. It is caused by some personality traits such as shyness, quietness, and fear of making mistakes. Aida (1994) claimed that learners who experience communication apprehension face difficulties when communicating with others or when they express themselves in a foreign language classroom, for instance, while speaking or participating in the lessons. Furthermore, researchers have claimed that communication apprehension is related to the learners' self-image.

\section{Test anxiety}

Toth (2010) defined test anxiety as "the tendency to view with alarm the consequences of inadequate performance in an evaluative situation." It is the fear of failure in evaluative situations such as written or oral tests and presentations; it might occur before, during or after a test. However, it is important to note that the oral test provokes the most anxiety in the classroom setting. (Horwitz et al., 1986). Researchers have claimed that test anxiety inhibits the students' performance in the foreign language learning process. 


\section{Fear of negative evaluation}

Fear of negative evaluation is defined as an "apprehension about others' evaluations, avoidance of evaluative situations, and the expectations that others would evaluate oneself negatively" (Horwitz et al., 1986). It is worth mentioning that fear of negative evaluation is similar to test anxiety. However, while Horwitz (1986) claimed that test anxiety might occur in test-taking situations, in contrast, fear of negative evaluation may happen in any social or academic evaluative situation. For example, in regular group discussions or while speaking a foreign language.

\section{Foreign Language Speaking Anxiety}

Many scholars assert that FLA is mostly observed in speaking classes (Gardner \& MacIntyre, 1993; Horwitz et al., 1986; MacIntyre, 1999; Young, 1992). Therefore, many researchers have conducted studies to investigate the effect of FLSA on EFL learners. FLSA may appear in various forms such as nonverbal behaviors like blushing, an unwillingness to speak or a refusal to make eye contact (Hashemi \& Abbasi, 2013).

There are several studies that have been carried out in relation to the students' FLSA. For instance, Heng et al. (2012) conducted a study to examine FLSA among Malaysian students. The results revealed that the students had a moderate level of speaking anxiety, and the sources of this anxiety were the fear of negative evaluation, speaking to native speakers and the fear of test failure. Furthermore, Price (1991) found that speaking in front of one's peers is a very anxiety-provoking situation for EFL learners. The fear of making pronunciation mistakes and the fear of negative evaluation are the major causes of FLSA.

Huang (2004) investigated FLSA among university students in Taiwan. The researcher found that the students had a high level of speaking anxiety. Similarly, Tisplakides and Keramida (2009) analysed Greek school students aged from 13 to 14 . The results indicated that the students experienced a high level of anxiety because of the fear of negative evaluation from their peers, and perceptions of low performance in comparison to their peers.

\section{The Sources of Foreign Language Speaking Anxiety}

Research has suggested that FLSA has different sources. Young (1990) identified many sources of FLSA including teacher-student interaction, teachers' beliefs about language learning, and students' beliefs about language learning, testing, and classroom teaching techniques. Moreover, Mak (2011) examined the sources of FLSA among Chinese EFL university students using a foreign language anxiety classroom scale (FLACS) questionnaire to gather the data. The results indicated five factors associated with FLSA: fear of negative evaluation, unease when speaking to native speakers, negative perceptions about the English classroom, negative self-evaluation, and fear of personal failure.

Liu (2006) conducted a study to investigate the sources of FLSA among Chinese students. The results indicated many sources: the lack of practice, limited vocabulary knowl- edge, low level of proficiency, fear of negative evaluation, imperfect grammar, and low-confidence. In addition, Öztürk and Gürbüz (2014) examined the sources of FLSA among Turkish students. The results highlighted pronunciation, immediate questions, fear of making mistakes, fear of negative evaluation as the major causes of FLSA. Furthermore, Hashim and Isa (2012) investigated the sources of FLSA among Malaysian students. The results revealed the fear of negative evaluation and low self-esteem as the main reasons for speaking anxiety. Furthermore, researchers have identified more specific sources of FLSA, some of which have been discussed in the following section.

\section{Sources associated with the learner}

Many researchers claimed that the main source of FLSA is the learner. Young (1991) stated that low self-esteem and competitiveness are the main sources of FLSA. Tsiplakides and Keramida (2009) found that students with FLSA believed that they were bad English speakers; they were afraid and worried that their peers would make fun of them and evaluate them negatively. Similarly, Aida (1994) stated that students with low self-esteem are more likely to have FLSA. This is because they have a negative self-perception and they are anxious about what their classmates think when they make mistakes. Yan and Horwitz (2008) argued that competitiveness can also be considered as a major source of FLSA. Thus, a competitive language learning environment may cause FLSA when language learners compare their speaking skills to their classmates.

\section{Sources associated with the teacher}

Many studies have pointed out that the negative attitudes of the teacher may cause FLSA. Subasi (2010) conducted a study to identify the sources of FLSA among Turkish learners. The results revealed that the participants had enlisted the teachers' attitudes towards their speaking errors as one of the main reasons of FLSA. For example, Young (1991) argued that teachers with more authority believed they had to correct all the students' errors, despite this being seen as the most anxiety-provoking behavior in the classroom. Similarly, MacIntyre (1999) asserted that teachers who continuously correct their students' errors cause FLSA since the error correction is done publicly.

\section{Sources associated with the methodology}

Several researchers have claimed that classroom procedures can be reported as the main source of FLSA, especially EFL classroom activities that require students to speak and participate in a foreign language. For example, Young (1990) asserted that activities requiring oral performance in front of others are the most anxiety-provoking activities for language learners. They also suggested that pair or group activities would help anxious learners to speak in the EFL classroom. Similarly, Daly (1991) reported that learners feel more anxious when they speak in a foreign language in front of others. 


\section{Foreign Language Speaking Anxiety in the Saudi Context}

The above-mentioned examples illustrate that there are several studies in the literature that investigate FLA. However, only a few of them focus on FLA in Saudi Arabia. For example, Javid (2014) conducted a study to identify the level and the sources of FLA among Saudi students using the FLACS. The results revealed that the students had a moderate level of anxiety and the most reported source was related to speaking anxiety. Similarly, Alrabai (2014) used FLACS to examine FLA among Saudi students. The findings revealed that the students had a moderate to high level of foreign language learning anxiety with speaking as the main factor. Moreover, a recent study was conducted by Sadiq (2017) to investigate the level of FLA among EFL female Saudi university students. The study was carried out with a quantitative research design using a FLACS survey. The results showed that the students experienced a moderate level of anxiety in the English language classroom.

One of the recent studies investigating FLSA in the Saudi context is Rafada's and Madini's (2017) study. They investigated FLSA sources among Saudi female students studying at an English language institute using a mixed-method approach. The results revealed that teachers' role in reducing anxiety and lack of vocabulary, the weak educational system in schools, test anxiety and peer anxiety are the main sources of FLSA. Moreover, Asif (2017) conducted a study using an identical research approach. However, the focus was on EFL teachers' perspectives of speaking anxiety. The study reported many sources of FLSA such as the negative impact of the first language, and the lack of a supportive classroom environment.

From the above studies, it might be concluded that few Saudi researchers have investigated the level and the sources of FLSA to identify its effect on the foreign language learning process. Therefore, the current study will focus on FLSA from the perspective of female Saudi students in a new context, which is the first year at King Saud University.

\section{Strategies to Reduce Foreign Language Speaking Anxiety}

There have been several methods, techniques, and solutions to reduce FLSA and create a less stressful foreign language learning environment. Horwitz et al. (1986) recommended that teachers have to support anxious students by considering an accurate method of error correction and creating a relaxed learning environment. Similarly, Young (1990) suggested some techniques to reduce FLSA such as providing a support group for anxious learners, using more pair or group work, playing language games, role-playing activities and encouraging the positive attributes of the EFL teacher such as friendliness, patience and a sense of humor.

In addition, Price (1991) pointed out that the teachers' positive behavior with their students may reduce FLSA, and the teacher should be "like a friend helping them to learn and less like an authority figure and making them perform freely". Furthermore, creating a supportive classroom environment is an effective tool to reduce FLSA. Gregersen and
MacIntyre (2014) claimed that creating a supportive and friendly classroom environment might inhibit FLSA, for it would mean an environment where competitiveness and self-comparisons were avoided.

\section{RESEARCH METHODOLOGY}

\section{Research Design}

The study used a descriptive methodology because it was appropriate for the nature and objectives of the study. To achieve the research objectives, a mixed-method approach was decided upon as an appropriate design for the current investigation. This led to mixing qualitative and quantitative research instruments in the same enquiry. According to Yan and Horwitz (2008), previous studies' reliance on questionnaires might not explain the role of anxiety in language learning in-depth. This may suggest the necessity of using qualitative methods such as interviews when investigating students' anxiety. In addition, Wang (2005) suggested combining both qualitative and quantitative methods to achieve a better understanding of FLSA. Therefore, the current study adopted the mixed-method approach to gain a deeper understanding of the FLSA.

\section{Research Questions}

This study sets out to answer the following two research questions:

1. To what extent do Saudi EFL university students experience Foreign Language Speaking Anxiety (FLSA)?

2. What are the perceived sources that may contribute to Foreign Language Speaking Anxiety (FLSA) among Saudi EFL university students?

\section{Pilot Study}

Once the questionnaire was translated into Arabic by the first researcher, a pilot study was conducted. To ensure the accuracy of the questionnaire items, the pilot study was conducted with five first year Saudi female EFL students at King Saud University. The purpose of piloting the questionnaire was to observe students' reactions to the clarity and simplicity of the items as well as to help measure the time needed to fill out the questionnaire. The five students who took part in the pilot study were not involved in the main study. Their suggestions and comments helped to apply some modifications. For example, a few words were unclear in some statements while two items had the same meaning so one of them was discarded. After piloting the questionnaire, the students participated in face to face semi-structured interviews to ensure the clarity and the appropriateness of the interview questions and to measure the time taken to complete the interview. In light of their opinions, the interview for this study was prepared in its final form.

\section{Participants}

\section{Questionnaire participants}

The questionnaire participants were 85 first year Saudi female EFL students at King Saud University in the city 
of Riyadh, Saudi Arabia. The participants were randomly selected according to their willingness to take part in the study. All of the participants of the study spoke Arabic as their native language. Moreover, most of the students' ages ranged from 18 to 20 years old.

\section{Interview participants}

The interview participants were six first year Saudi female EFL students at King Saud University. The method for selecting the interview participants was based on their questionnaire scores; respondents with the highest level of foreign language speaking anxiety, who were willing to be interviewed, participated in the current study.

\section{Instruments}

To investigate the students' level and sources of FLSA, a questionnaire and a semi-structured interview were used. Although there are different instruments used to measure the level and sources of foreign language anxiety, the most commonly used tool to investigate the level and the sources of FLSA are FLACS created by Horwitz et al. (1986) and Young's (1990) questionnaire. These questionnaires are related to anxiety stemming from speaking the English language (MacIntyre \& Gardner, 1989), which is most relevant to the current investigation. Certain items from these two instruments were adopted and modified in the present study.

The FLACS included 33 items, a self-reported questionnaire using a five-point Likert scale from 1 (strongly agree) to 5 (strongly disagree). Aida (1994) argued that FLACS is mainly related to speaking anxiety and might not be consistent for investigating the level and sources of other types of FLA such as listening, writing or reading anxiety. Many FLACS items focus on examining FLA in relation to the oral performance aspects of language learning (MacIntyre \& Gardner, 1989). This questionnaire has been widely used by several researchers (eg., Rafada \& Madini, 2017; Heng et al., 2012; Sadighi \& Dastpak, 2017). Young's (1990) questionnaire was established to increase the previously reported findings of FLA sources. It aims to investigate the level and the sources of FLSA by identifying the classroom activities causing speaking anxiety.

\section{The development of the questionnaire}

Google forms online service was used to construct the questionnaire, which consisted of 26 closed-ended items and was divided into three sections. The questionnaire items were adopted and modified. In the adaptation, the term "foreign language" in the FLACS was replaced with the term "English language" to make it more relevant to the current investigation. The questionnaire introduced a summary of the research and its objectives, representing the privacy of the participants' information and their answers. It also included a question asking the participants if they had agreed to participate in the study voluntarily.

The first section of the questionnaire asked the participants to provide their contact information such as their name and phone number for a follow-up interview. The second section of the questionnaire consisted of seven items and was adopted from FLACS. The purpose of this section was to identify the level of FLSA. The third section consisted of 19 items and it was intended to identify the sources and the type of classroom situations that caused FLSA. Nine items were adapted and modified from the FLACS. Moreover, five items were adapted and modified from Young's questionnaire. Five items were created and added based on a review of the FLSA sources in the literature.

\section{Procedure}

\section{Collecting quantitative data}

The questionnaire was distributed to 85 Saudi female EFL students in the first year at King Saud University. The participants took 5 to 8 minutes to complete the questionnaire. The first researcher attended the participants' classes and gave them a summary of the study and its objectives. The students were allowed to ask questions about the questionnaire, while the first researcher asked them to share its link online. The data collection took about three weeks.

\section{Collecting qualitative data}

The semi-structured interviews were conducted with five first year Saudi female EFL students at King Saud University. They demonstrated a high level of foreign language speaking anxiety and agreed to be interviewed. The interview lasted for 10 to 15 minutes.

\section{Data Analysis}

\section{Questionnaire}

Statistical Package for Social Sciences (SPSS) software was used to analyse the quantitative data. After coding and data entry into the computer, and specifying the length of Likert scale, the quintet cells (maximum and minimum) that were used in the study pivoted the calculated degree $(5-1=4)$, which was divided into scale cells in order to obtain correct cell length $(4 / 5=0.80)$. Subsequently, this value was added to the lesser value in the scale (or to the beginning of the scale which is an integer one), which is to specify the maximum of this cell according to the length of cells. After that, the following statistical measures were calculated: Frequency and Percent, Weighted Mean, Mean and Standard Deviation.

\section{Interviews}

In the current investigation, the interviews were conducted in Arabic to avoid misunderstanding, and the interviews were audio-recorded and transcribed by the first researcher. The interview data were analysed under the principle of content analysis, that is, the data were analysed to coding themes. The data were first transcribed into a textual form in the original language (Arabic), and then, the interviews were translated into (English). The data were coded for emergent themes and patterns. This process involved highlighting 
extracts of the transcribed data under various labels in order to be clearly identified.

\section{RESULTS}

\section{Results of the First Research Question}

To what extent do Saudi EFL university students experience Foreign Language Speaking Anxiety (FLSA)?

\section{Questionnaire results}

To answer the first question, the first section of the questionnaire was used consisting of seven items to identify the students' level of FLSA. The total average score (ranging from 1 to 5) was calculated. The average score was used as an index of the students' level of speaking anxiety; the higher the average, the more anxious the respondents felt. The categorisation of anxiety used in the current study is similar to the categorisation that researchers such as Al-Saraj (2011) and Javid (2014) used to determine the learners' level of speaking anxiety, and can be seen in Table 1 .

The total average mean score was 3.32, which falls within the range of the moderately anxious participant. Therefore, as a result of the statistical analysis of the first research question, it was found that the overall level of foreign language speaking anxiety was moderate. It can thus be said that the participants in this study are moderately anxious about speaking in an EFL class.

\section{Interview results}

In order to analyse the level of FLSA more deeply, six of the most anxious students were interviewed. The semi-structured interview data were coded for emergent themes and patterns, and then, these themes were put into categories. The first interview question was "Some people might feel anxious when they speak the English language. How do you feel when you speak English in the class?"

Some of the students' responses to this question can be seen below:

Student 1 "I don't feel good at all. Actually, I feel bad and also I feel very stressed. Sometimes I stutter when I speak English and my hands sweat."

Student 4 "Anxious. The stress that I feel ruins everything. Sometimes even if I know what to say and how to say it. I can't say it because I am so stressed. Sometimes when the teacher asks me to answer a question in English, even

Table 1.The categories used to determine the level of speaking anxiety

\begin{tabular}{ll}
\hline Mean score & Category \\
\hline 1 TO 1.79 & "very un-anxious" \\
1.80 TO 2.59 & "un-anxious" \\
2.60 TO 3.49 & "moderately anxious" \\
3.50 TO 4.29 & "anxious" \\
4.30 TO 5 & "highly anxious" \\
\hline
\end{tabular}

though I know the answer I can't say it aloud because of my stress."

Student 5 "I feel very stressed. I have a negative feeling when I speak English because I know how to speak when I'm alone but I can't speak in front of my classmates"

The above-stated results make it clear that the majority of the study individuals feel anxious and stressed in their English class. The qualitative data was also supportive of the quantitative findings. The students who participated in the study were anxious in their English class.

\section{Results of the Second Research Question}

What are the perceived sources that may contribute to Foreign Language Speaking Anxiety (FLSA) among Saudi EFL university students?

\section{Questionnaire results}

The second part of the questionnaire that consisted of nineteen items was analysed to identify the students' sources of FLSA. It revealed that the students experienced various sources of FLSA. Fear of making mistakes comes in first place with a mean of (4.41). Fear of making mistakes when speaking English is the most reported factor that causes FLSA. The factor of forced participation comes in second place with a mean of (4.38). Students feel that forcing them to participate in their English class causes their speaking anxiety. Lack of vocabulary comes in third place with a mean of (3.79). Lack of English vocabulary was identified as a major source of students' speaking anxiety. Lack of practice comes in at fourth place with a mean of (3.75). Limited English speaking practice was considered as one of the main sources of students' speaking anxiety. Lack of grammatical knowledge comes in at fifth place with a mean of (3.71). The difficulties in applying grammatical rules are one of the main sources of students' English speaking anxiety. Students also reported other factors such as lack of preparation, fear of making pronunciation mistakes and giving oral presentations.

\section{Interview results}

In order to deeply investigate students' perceived sources contributing to FLSA, semi-structured interviews were conducted with six of the most anxious participants who were assessed in the questionnaire. The semi-structured interview data were coded for emergent themes and patterns, these themes were then put into categories. The second interview question was "From your point of view, what are the sources of stress and anxiety when speaking English in the class?". The questionnaire findings were further supported in the interviews. The following are examples of students' responses:

Student 1 "In my opinion, I feel anxious because I don't have enough vocabulary and grammar. I think if I knew more vocabulary or how to form a correct sentence I wouldn't be nervous at all. Also, I am afraid of making mistakes, because most of the students in my class are better than me when they speak English. That is why I avoid speaking because they are better English speakers." 
Student 4 "I think, first, the lack of practice, we didn't speak English at school, the high school teacher she didn't even speak English in our English class, if they teach us how to speak English at school we wouldn't struggle like that at university, the second reason is my fear of making mistakes, I am shy person, I don't like to make mistakes especially in front of people that I don't know"

Student 6 "Personally I have two reasons. The first is grammar so I can't form correct sentence, the second reason is that I'm afraid of making mistakes. I don't want my classmates to laugh at me."

Student 2 "I believe that the main reasons for my anxiety are lack of English vocabulary and grammar and the fear of making pronunciation mistakes. I don't want my classmates to laugh at me when I pronounce the words incorrectly."

The above-stated results clarify that the qualitative data also support the quantitative findings. The interview results indicate that students who participated in the study felt anxiety in their English class because of several sources of FLSA. The first factor is the fear of making mistakes. The students felt that speaking exposed their mistakes and they thought that if they made mistakes, other students would doubt their abilities. The second factor is the lack of vocabulary knowledge and correct grammar rules. The students reported that their lack of vocabulary and grammar affected their speaking performance negatively; they felt anxious and nervous. Students also reported other sources of their speaking anxiety such as lack of English speaking practice, and fear of making pronunciation mistakes.

Furthermore, to understand FLSA sources more deeply students were asked the following question: "What are the situations or the classroom activities that made you feel anxious when you speak English in the class?" The students' responses show that oral presentations represent the highest anxiety-provoking activity in the English class. For example:

Student 1 "Presentations, I don't like to do presentations even in Arabic. When I did my presentation I forgot all the things that I was supposed to say. Actually, when I stood up in front of my classmates I forgot everything because I was so nervous."

Student 2 "Presentations, I practiced my presentation, for days but when I stood up in front of my classmates I forgot everything. I was very nervous actually, I felt my heartbeat so fast, I was so embarrassed, so I looked at my notes and tried to continue the presentation."

Student 6 "I don't like to speak in my English class. I don't like to participate, also, when I did my presentation I was so anxious, I sweat and I stuttered, the teacher told me I could look and read, but I couldn't see anything. So I took a few minutes and then I tried again and it worked"

Moreover, to identify teachers' role in FLSA, the students were asked: "What do you think your teacher's role in influencing your feeling of speaking anxiety in English classroom?"; some of the students' answered as follow:

Student 1 "My teacher was very nice. She tried to help me by giving me instructions and correcting my mistakes. But she never spoke Arabic in class. That bothered me since I can't understand the lessons. My other English teacher explains some things in Arabic, that helped me a lot."
Student 2 "She is the main reason of my stress, she is evil, she laughed at me when I made mistakes, she didn't correct my mistakes. Instead of that, she made fun of me"

Student 3 "God bless her heart, she was so kind and compassionate with me, when I made a mistake she came close to me and corrected my mistakes quietly, she never spoke loudly in front of the class so she didn't embarrass me."

Student 4 "My teacher was so nice, she accepted my mistakes and tried to correct them, she was smiling that's made me comfortable in her class."

The results of these questions show that oral presentations are considered as the highest anxiety-provoking factor in the EFL classroom. The students in this study reported that presentations made them very anxious and stressed. Moreover, the teacher has a role in influencing FLSA. The students in this study reported that the teachers, who were kind, smiling and accepting of their students' mistakes, were the ones who reduced their FLSA. This is unlike the teachers who have a negative attitude towards students' mistakes.

\section{DISCUSSION}

The results revealed that the female Saudi EFL university students experienced a moderate level of speaking anxiety in the classroom. There are several studies reporting a moderate level of FLSA among EFL learners in different contexts such as those by Javid (2014) and Alrabai (2014) in the Saudi context, Heng et al. (2012) in the Malaysian context, Tianjian (2010) in the Chinese context, and Cagatay (2015) in the Turkish context. A moderate level of speaking anxiety seems to be acceptable but is still considered to feel alarming and needs to be dealt with. FLSA might discourage students from expressing their thoughts in English and negatively affect their speaking performance in the EFL class. Horwitz et al. (1986) stated that anxious students could "skip classes, overstudy, or seek refuge in the last row in an effort to avoid the humiliation or embarrassment of being called on to speak" (p.130). Thus, in order to understand the sources of students' moderate level of speaking anxiety, it is essential to investigate the possible sources of FLSA.

Furthermore, the results revealed that there are several sources that may contribute to FLSA among Saudi EFL university students. The overall analysis of the quantitative and qualitative data indicates that the sources related to FLSA follow the order below:

First, students in the current study are afraid to make mistakes in front of their peers. The fear of making mistakes in speaking EFL has been reported as an anxiety-provoking factor in previous studies such as Horwitz's (1986) research where it was found that the fear of making speaking mistakes prevented students from participating in their English class. In addition, Gregersn and Horwitz (2002) claimed that the students' fear of making mistakes is negatively associated with a concern to save their positive image. As a result, students hesitate to speak and avoid the risk of making mistakes. These findings seem to corroborate other studies 
(Horwitz et al., 1986; Young, 1991) which proposed that students' fear of making mistakes might be connected to teachers' method of correcting their students' errors. This was evident in the qualitative data when the interviewed students expressed their concerns about the negative attitudes of their teachers when they corrected their mistakes.

Second, forced participation was also problematic; some EFL teachers forced their students to participate and to answer immediate questions. The majority of students in this study preferred to volunteer answers rather than being called upon in front of their classmates. These findings reinforced the results of previous studies such as William and Andrade (2008) who claimed that forcing students to answer immediate questions before they were prepared, created FLSA for them.

Third, students reported that they had FLSA because of their limited vocabulary knowledge. Moreover, students who participated in the interviews reported that limited English vocabulary caused their FLSA. There are previous studies (eg., Rafada \& Madini, 2017; Taneever, 2007) that are in line with these findings, which found that the students' limited vocabulary is one of the main sources of FLSA.

The fourth source is the lack of practice. Students' limited English language speaking practice is a major factor in their FLSA. Indeed, students in this study reported that they felt anxious because they did not have the chance to practice speaking in their English class. The qualitative data support the quantitative data along with the students being concerned about their lack of practice in the EFL classroom. There are several studies that indicate the major influence of limited practice on the students' FLSA. For example, Alsaraj (2014) found that the English language in the Saudi context was taught as a subject so the students had limited classes and limited time to practice the language.

Fifth, the lack of grammatical knowledge was found to be a major FLSA source. Students in the current study indicated that they felt anxious when speaking English because they felt that they were using incorrect grammar while they spoke. There are other studies reporting that grammar is a major source for students' FLSA (e.g., Taneever, 2007; Wu, 2010).

The students in this study mentioned other FLSA provoking factors such as fear of making pronunciation mistakes. Incorrect pronunciation is one of the major FLSA factors with students in this study conceding that they were embarrassed about possibly being mocked by the other students. In addition, giving oral presentations is considered as a highly stressful activity. The students reported that they got stressed and confused if asked to present in front of their classmates. Moreover, the students mentioned their teachers' negative attitudes as a further anxiety-provoking factor. This finding is also reflected in a number of studies (eg., Toth, 2010; Young, 1990).

\section{CONCLUSION}

This study aimed to investigate the level of speaking anxiety and its sources among Saudi EFL university students.
To achieve this aim, a mixed-method research design was implemented. Two research instruments were used, a questionnaire and semi-structured interviews. The results showed that the students had a moderate level of foreign language speaking anxiety in the English classroom. In addition, the results revealed that there are several sources related to FLSA. These factors follow this order: fear of making mistakes, forced participation, lack of vocabulary, lack of practice, lack of grammatical knowledge. Students also reported other factors such as, lack of preparation, teachers' negative attitude, fear of making pronunciation mistakes and giving oral presentations.

Based on the findings of this study, it could be concluded that FLSA has a debilitating effect on English language learning. In summary, it is essential that EFL teachers and learners are aware of FLSA and its various sources. Moreover, teachers should use different strategies and applications help their students to overcome their FLSA according to their needs.

\section{Suggestions for Future Research}

For future research, it is suggested that researchers go beyond the limitations of this study. This study was conducted with first year female Saudi EFL university students. This could be applied to a different group of students. For example, female students from different majors and colleges or with male students. Another suggestion for future research is to investigate the level and the sources of FLSA in other English language skills such as listening, reading and writing.

\section{Recommendations}

Based on the findings of the current study, a number of recommendations are put forward. These may reduce foreign language speaking anxiety of learners. The recommendations include the following:

1. The teachers' role is to accept the students' mistakes and consider them as common while speaking English. As it is a part of the learning process, teachers should not make a big deal out of speaking mistakes and should correct them in a respectful way.

2. Teachers should provide familiar speaking topics to their students.

3. The students mentioned that large classes made them anxious. Therefore, smaller classes could reduce FLSA.

4. Students prefer to volunteer answers rather than being forced to participate. The teacher should give students the chance to participate.

5. Teachers should encourage students to practice speaking in pairs or small groups; since getting more practice in speaking in English helps to reduce students' FLSA, they will become more confident while speaking English.

6. Students who have FLSA can attend specialised speaking courses to help them overcome their anxiety.

7. Ample time should be given to students to prepare answers. 
8. Interesting speaking topics should be used in speaking activities since that might encourage students to participate more effectively.

\section{REFERENCES}

Aida, Y. (1994). Examination of Horwitz, Horwitz, and Cope's construct of foreign language anxiety: The case of students of Japanese. The Modern Language Journal, 78(2), 155-168.

Alrabai, F. (2014). A model of foreign language anxiety in the Saudi EFL context. English language teaching, 7(7), 82-101.

Al-Saraj, T. M. (2014). Foreign language anxiety in female Arabs learning English: Case studies. Innovation in Language Learning and Teaching, 8(3), 257-278.

Asif, F. (2017). The anxiety factors among Saudi EFL learners: A study from English language teachers' perspective. English Language Teaching, 10(6), 160-173.

Daly, J. (1991). Understanding communication apprehension: An introduction for language educators. Language anxiety: From theory and research to classroom implications, 9(1), 3-13.

Gardner, R. C., \& MacIntyre, P. D. (1993). On the measurement of affective variables in second language learning. Language Learning, 43(2), 157-194.

Gregersen, T., MacIntyre, P. D., \& Meza, M. D. (2014). The motion of emotion: Idiodynamic case studies of learners' foreign language anxiety. The Modern Language Journal, 98(2), 574-588.

Hashemi, M., \& Abbasi, M. (2013). The role of the teacher in alleviating anxiety in language classes. International Research Journal of Applied and Basic Sciences, 4(3), 640-646.

Hashim, H., \& Isa, I. S. M. (2012). Students' anxiety level towards speaking in English: Malaysia polytechnic experience. In 2012 IEEE Symposium on Business, Engineering and Industrial Applications (pp. 595-599). IEEE.

Heng, C. S., Abdullah, A. N., \& Yusof, N. (2012). Investigating the construct of anxiety in relation to speaking skills among ESL tertiary learners. 3L: Language, Linguistics, Literature, 18(3).

Horwitz, E.K. (1990). Attending to the affective domain in the foreign language classroom. In S. Magnan (Ed.), Shifting the instructional focus to the learner (pp. 1533). Middlebury, VT: Northeast Conference on the Teaching of Foreign Languages.

Horwitz, E. (2001). Language anxiety and achievement. Annual review of applied linguistics, 21, 112-126.

Horwitz, E. K., Horwitz, M. B., \& Cope, J. (1986). Foreign language classroom anxiety. The Modern Language Journal, 70(2), 125-132.

Horwitz, E. K., \& Young, D. J. (1991). Language anxiety: From theory and research to classroom implications. Englewood Cliffs, N.J: Prentice Hall.

Huang, H. W. (2004). The relationship between learning motivation and speaking anxiety among EFL non-English major freshmen in Taiwan [Unpublished master's thesis]. Chaoyang University of Technology.
Javid, C. Z. (2014). Measuring language anxiety in an EFL context. Journal of Education and Practice, 5(25), $180-193$

Liu, M. (2006). Anxiety in EFL classrooms: Causes and consequences. TESL Reporter, 39(1), 13-32.

MacIntyre, P. D., \& Gardner, R. C. (1989). Anxiety and second-language learning: Toward a theoretical clarification. Language Learning, 39(2), 251-275.

MacIntyre, P. D., \& Gardner, R. C. (1991). Methods and results in the study of anxiety and language learning: A review of the literature. Language Learning, 41(1), 85-117.

Mak, B. (2011). An exploration of speaking-in-class anxiety with Chinese ESL learners. System, 39(2), 202-214.

Nahavandi, N., \& Mukundan, J. (2013). Foreign language learning anxiety among Iranian EFL learners along gender and different proficiency levels. Language in India, 13(1).

Öztürk, G., \& Gürbüz, N. (2014). Speaking anxiety among Turkish EFL learners: The case at a state university. Journal of Language and Linguistic Studies, 10(1), $1-17$.

Price, M. L. (1991). The subjective experience of foreign language anxiety: Interviews with highly anxious students. Language anxiety: From theory and research to classroom implications, 101-108.

Rafada, S., \& Madini, A. (2017). Major causes of Saudi learners' speaking anxiety in EFL classrooms. International Journal of English Language Education, 5 (1), 54-71.

Sadighi, F., \& Dastpak, M. (2017). The sources of foreign language speaking anxiety of Iranian English language learners. International Journal of Education and Literacy Studies, 5(4), 111-115.

Sadiq, J. M. (2017). Anxiety in English language learning: A case study of English language learners in Saudi Arabia. English Language Teaching, 10(7), 1-7.

Subasi, G. (2010). What are the main sources of Turkish EFL students' anxiety in oral practice?. Online Submission, 1(2), 29-49.

Szyszka, M. (2017). Pronunciation Learning Strategies and Language Anxiety. Springer, Cham.

Tianjian, W. (2010). Speaking anxiety: More of a function of personality than language achievement. Chinese Journal of Applied Linguistics (Foreign Language Teaching \& Research Press), 33(5).

Toth, Z. (2010). Foreign language anxiety and the advanced language learner: A study of Hungarian students of English as a foreign language. Cambridge Scholars Publishing.

Tsiplakides, I., \& Keramida, A. (2009). Helping students overcome foreign language speaking anxiety in the English classroom: Theoretical issues and practical recommendations. International Education Studies, 2(4), 39-44.

Wang, N. (2005). Beliefs about language learning and foreign language anxiety: A study of university students learning English as a foreign language in Mainland Chi- 
na [Unpublished MA dissertation]. University of Victoria, British Colombia.

Wu, K. H. (2010). The Relationship between Language Learners' Anxiety and Learning Strategy in the CLT Classrooms. International Education Studies, 3(1), 174-191.

Yan, J. X., \& Horwitz, E. K. (2008). Learners' perceptions of how anxiety interacts with personal and instructional factors to influence their achievement in English: A qualitative analysis of EFL learners in China. Language Learning, 58(1), 151-183.
Young, D. J. (1990). An investigation of students' perspectives on anxiety and speaking. Foreign Language Annals, 23(6), 539-553.

Young, D. J. (1991). Creating a low-anxiety classroom environment: What does language anxiety research suggest?. The modern language journal, 75(4), 426-437.

Young, D. J. (1992). Language anxiety from the foreign language specialist's perspective: Interviews with Krashen, Omaggio Hadley, Terrell, and Rardin. Foreign Language Annals, 25(2), 157-172. 